\title{
Experimental Analysis of Concrete with Quarry Dust and Demolished Concrete Waste
}

\author{
N.Devendran ${ }^{1}$, D.Mohan Kumar $^{2}$ \\ ${ }^{1}$ Assistant Professor, Department of Civil Engineering JAYA SURIYA ENGINEERING COLLEGETamil Nadu, \\ India \\ ${ }^{2}$ Lecturer, Department of Civil Engineering VELTECH POLYTECHNIC COLLEGE Tamil Nadu, India
}

\begin{abstract}
The use of Recycle product is increasing with innovation in present scenario. The utilization of waste product in the manufacturing of new product is a challenging job. The Natural Resource decreases in a short period and therefore the use of waste product is necessary. In the construction field of the world, use of Demolished Concrete Waste as alternative of coarse aggregate plays a vital role to save natural resources and economically good for us. Natural sand is a prime material used for the preparation of concrete and also plays an important role in Mix Design. One such material is Quarry stone dust: a by-product obtained during quarrying process. Attempts have been made to study the suitability of Quarry Dust as sand replacing material and it has been found that Quarry Dust improves the mechanical properties of concrete as well as elastic modulus. This present work is an attempt to use Quarry Dust as partial replacement for fine aggregate in concrete and Demolished Concrete Waste as partial replacement for coarse aggregate in concrete. The main object of this project is to determine the Compressive strength, Split tensile strength, Flexural strength. Various mixes were prepared for carrying out the research by varying the proportions of cement, sand and aggregates. All mixes were designed for characteristic strength $\left(f_{\mathrm{ck}}\right)$ of M20. The Compressive strength, Split tensile strength, Flexural strength of concrete was tested in laboratory after 7, 14 and 28 days.
\end{abstract}

Keywords: Concrete, Natural Sand, Quarry Dust, Natural Coarse Aggregate Demolished Concrete Waste.

\section{INTRODUCTION}

Concrete is the premier construction material across the world and the most widely used in all types of civil engineering works, including infrastructure, low and high-rise buildings, defense installations, environment protection and local/domestic developments. Concrete is a manufactured product, essentially consisting of cement, aggregates, water and admixture(s).

Among these, aggregates, i.e. inert granular materials such as sand, crushed stone or gravel form the major part. Traditionally aggregates have been readily available at economic price. However, in recent years the wisdom of our continuedwholesale extraction and use of aggregates from natural resources has been questioned at an international level. This is mainly because of the depletion of quality primary aggregates and greater awareness of environmental protection. In light of this, the availability of natural resources to future generations has also been realized. Given this background, the concept of sustainable development put forward almost a decade ago, at the 1992 Earth Summit in Rio de Janeiro, and it has now become a guiding principle for the construction industry worldwide.

Quarry dust, a byproduct from the crushing process of stones (Blue metal) which is available abundantly from rock quarries at low cost in many areas can be an economical alternative to the river sand. Quarry dust can be defined as residue, tailing material after the extraction and processing of rocks to form fine particles less than $4.75 \mathrm{~mm}$. Quarry dust, which is generally considered as a waste material, causes an environmental load due to disposal problem. Quarry dust being by and large, a waste product, will also reduce environmental impact, if consumed by construction industry in large quantities. Hence, the use of quarry dust as fine aggregate in concrete will reduce not only the demand for natural sand but also reduces the environmental problems. Moreover, the incorporation of quarry dust will offset the production cost of concrete and hence, the successful utilization of quarry dust as fine aggregate will turn this waste material into valuable resource.

Construction waste is generated whenever any construction/demolition activity takes place, such as, building roads, bridges, fly over, subway, remodeling etc. It consists mostly of inert and nonbiodegradable material such as concrete, plaster, metal, wood, plastics etc. A part of this waste comes to the municipal stream. These wastes are heavy, having high density, often bulky and occupy considerable storage space either on the road or communal waste bin/container. It is not uncommon to see huge piles of such waste, which is heavy as 
well, stacked on roads especially in large projects, resulting in traffic congestion and disruption.

\section{EXPERIMENTAL INVESTIGATIONS 2.1 MATERIALS}

2.1.1 Cement: In this experimental investigation Ordinary Portland cement of 53 grade is used The properties of Cement are as follows in table 2.1:

TABLE 2.1. PROPERTIES OF CEMENT

\begin{tabular}{|l|l|l|}
\hline S.No & Property & Value \\
\hline 1. & Specific Gravity & 3.15 \\
\hline 2. & Initial Setting Time & 87 minutes \\
\hline 3. & Standard Consistency & $33 \%$ \\
\hline 4. & Fineness & 1.75 \\
\hline
\end{tabular}

2.1.2 Fine Aggregate: Natural river sand with fraction passing through $4.75 \mathrm{~mm}$ sieve and on $150 \mu \mathrm{m}$ sieve was used and tested as per IS: 23861983. The important properties tested for the aggregate are given below in the table 2.2

TABLE 2.2 PROPERTIES OF FINE AGGREGATE

\begin{tabular}{|l|l|l|}
\hline S.No & Property & Value \\
\hline 1. & Specific Gravity & 2.64 \\
\hline 2. & Fineness modulus & 2.73 \\
\hline 3. & Water absorption & 1.24 \\
\hline
\end{tabular}

2.1.3 Coarse Aggregate: crushed granite coarse aggregate of size $15.5 \mathrm{~mm}$ was used and tested as per IS:2386-1983.The important properties tested for coarse aggregates are given below in the table 2.3

TABLE2.3 Properties Of Coarse Aggregate

\begin{tabular}{|l|l|l|}
\hline S.No & Property & Value \\
\hline 1. & Specific Gravity & 2.76 \\
\hline 2. & Water absorption & 0.54 \\
\hline
\end{tabular}

2.1.4 quarry dust : Quarry dust, a byproduct from the crushing process of stones (Blue metal) which is available abundantly from rock quarries at low cost in many areas can be an economical alternative to the river sand. Quarry dust can be defined as residue, tailing material after the extraction and processing of rocks to form fine particles less than $4.75 \mathrm{~mm}$. The properties of silica fume shown in the table 2.4

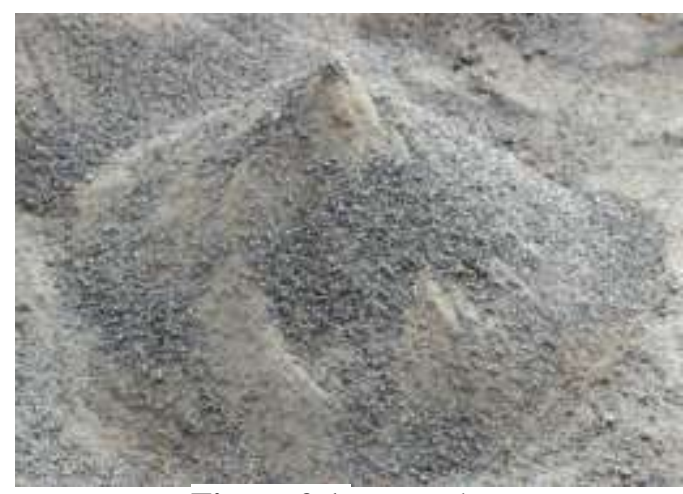

Figure 2.1 quarry dust

TABLE 2.4.Properties Of Quarry Dust

\begin{tabular}{|c|c|c|}
\hline S.No & $\begin{array}{l}\text { Properties and } \\
\text { composition }\end{array}$ & Value \\
\hline 1. & Specific gravity & $2.54-2.60$ \\
\hline 2. & $\begin{array}{l}\text { Bulk density } \\
(\mathrm{kg} / \mathrm{m} 3)\end{array}$ & $1720-1810$ \\
\hline 3. & Absorption (\%) & $1.20-1.50$ \\
\hline 4. & $\begin{array}{c}\text { Moisture } \\
\text { Content (\%) }\end{array}$ & Nil \\
\hline 5. & $\begin{array}{c}\text { Fine particles less than } \\
0.075 \mathrm{~mm}(\%)\end{array}$ & $12-15$ \\
\hline 6. & Sieve analysis & Zone-II \\
\hline 7. & $\mathrm{SiO} 2$ & 62.48 \\
\hline 8. & $\mathrm{Al} 2 \mathrm{O} 3$ & 18.72 \\
\hline 9. & $\mathrm{Fe} 2 \mathrm{O} 3$ & 6.54 \\
\hline 10. & $\mathrm{MgO}$ & 2.56 \\
\hline 11. & $\mathrm{Na} 2 \mathrm{O}$ & Nil \\
\hline 12. & $\mathrm{~K} 2 \mathrm{O}$ & 3.18 \\
\hline 13. & $\mathrm{TiO} 2$ & 1.21 \\
\hline 14. & Loss of ignition & 0.48 \\
\hline
\end{tabular}

\subsubsection{Demolished Concrete Waste}

When structures made of concrete are demolished or renovated, concrete recycling is an increasingly common method of utilizing the rubble. Concrete was once routinely trucked to landfills for disposal, but recycling has a number of benefits that have made it a more attractive option in this age of greater environmental awareness, more environmental laws, and the desire to keep construction costs down. The properties of rice husk ash is shown in the table 2.5

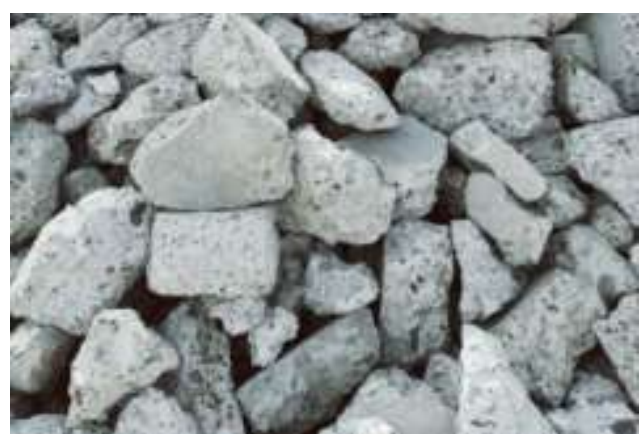

Figure 2.2 demolished concrete waste. 
TABLE 2.4. PROPERTIES OF Demolishe Concrete Waste

\begin{tabular}{|l|c|c|}
\hline S.No & $\begin{array}{c}\text { Properties and } \\
\text { composition }\end{array}$ & Value \\
\hline 1. & Specific Gravity & 2.72 \\
\hline 2. & Bulk Density(kg/m3) & 1741 \\
\hline 3. & Water absorption & 1.73 \\
\hline 4. & $\begin{array}{c}\text { Aggregate Impact } \\
\text { Value (\%) }\end{array}$ & 8.55 \\
\hline
\end{tabular}

\section{MIX PROPORTIONS}

Mix design is carried out as per EFNARC Specifications which satisfied the workability test methods on concrete. The MIX PROPORTIONS of SCC as shown in the table 2.5.

TABLE 2.5. MIX PROPORTIONS

\begin{tabular}{|l|c|}
\hline Cement & $394 \mathrm{~kg} / \mathrm{m}^{3}$ \\
\hline Fine aggregate & $644.37 \mathrm{~kg} / \mathrm{m}^{3}$ \\
\hline Coarse aggregate & $1197.61 \mathrm{~kg} / \mathrm{m}^{3}$ \\
\hline water & $197 \mathrm{~kg} / \mathrm{m}^{3}$ \\
\hline
\end{tabular}

\section{WORKABILITY TEST METHODS}

4.1.1 Slump Flow Test: The slump flow is used to assess the horizontal free flow of Self Compacting Concrete in the absence of obstruction. This method is based on the test method for determining the slump.

\section{SPECIMEN PREPARATION}

Concrete cubes specimens $(150 \mathrm{~mm}$ x 150 $\mathrm{mm} \times 150 \mathrm{~mm})$ for 45 cubes were casted for computing compressive strength. The cylindrical specimens (diameter- $150 \mathrm{~mm}$ and length- $300 \mathrm{~mm}$ ) for 30cylinders were casted to determine spilt tensile strength of concrete. The prism specimens $(150 \mathrm{~mm}$ x $150 \mathrm{~mm} \times 150 \mathrm{~mm}$ ) for 30prisms were casted for computing flexural strength. All the specimens were cured for a period of 28 days before test.

\section{RESULTS AND DISCUSSIONS}

After a detailed study we have obtained the following results for compression, split tensile strength and flexural strength.

\subsection{COMPRESSIVE STRENGTH}

The specimen is tested by compression test machine after 7 days, 14 days and 28 days curing. Load should be applied gradually at the rate of $140 \mathrm{~kg} / \mathrm{cm}^{2}$ per minute till specimens fails. Load at the failure divided by area of specimen gives the compressive strength of concrete.

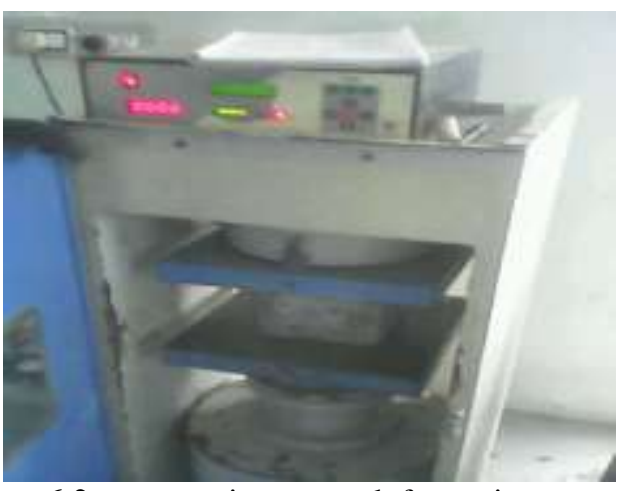

Figure 6.2 compressive strength for various proport

TABLE 6.1 RESULTS FOR COMPRESSIVE STRENGTH

\begin{tabular}{|c|l|c|}
\hline Sl.No. & \multicolumn{1}{|c|}{ Replacement details } & $\begin{array}{c}\text { Compressive } \\
\text { strength } \\
\text { N/mm }\end{array}$ \\
\hline 1. & Nominal Mix & $\mathbf{1 6 . 9}$ \\
\hline 2. & $\begin{array}{l}\text { Nominal Mix River sand } \\
(60 \%)+\text { Quarry Dust } \\
(40 \%)\end{array}$ & \multicolumn{1}{|c|}{$\mathbf{1 6 . 3}$} \\
\hline 3. & C.A (60\%) + DCW 40\%) & $\mathbf{1 8 . 6}$ \\
\hline 4. & $\begin{array}{l}\text { River sand (60\%) + } \\
\text { Quarry Dust (40\%) \& } \\
\text { C.A (60\%) + DCW } \\
(40 \%)\end{array}$ & $\mathbf{1 7 . 1}$ \\
\hline
\end{tabular}

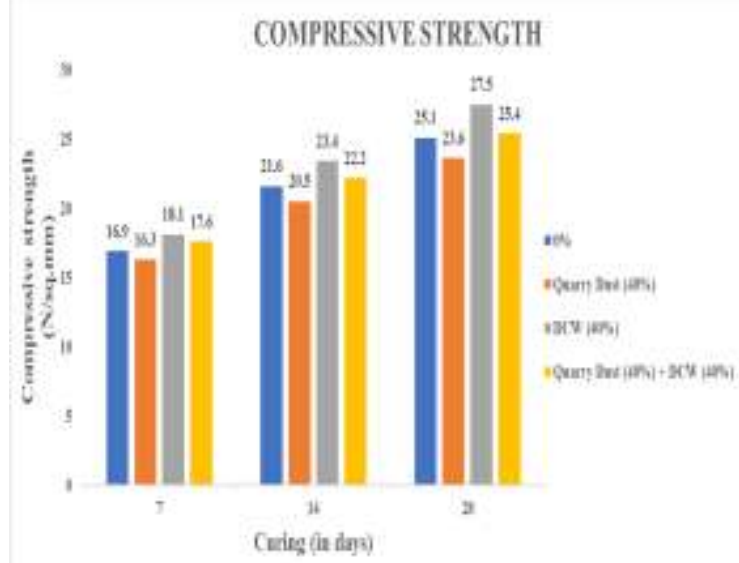

\subsection{SPLIT TENSILE STRENGTH}

The tensile strength of concrete is one of the basic and important properties. Splitting tensile strength test on concrete cylinder is a method to determine the tensile strength of concrete. The concrete is very weak in tensile due to its brittle nature and is not expected to resist the direct tension. The concrete develops cracks when subjected to 
tensile forces. Thus, it is necessary to determine the tensile strength of concrete to determine the load at which the concrete members may cracks.

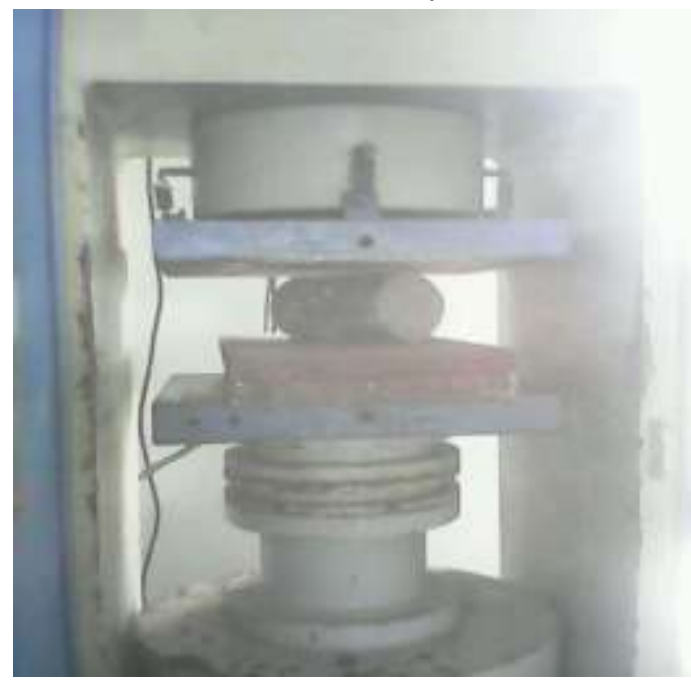

Figure 6.3 split tensile testing machine

TABLE 6.2 RESULTS FOR SPLIT TENSILE STRENGTH

\begin{tabular}{|l|l|l|}
\hline Replacement Details & $\begin{array}{l}\text { 14 days } \\
\text { (N/mm } \\
\text { ) }\end{array}$ & $\begin{array}{l}\mathbf{2 8 ~ d a y s ~} \\
\text { (N/mm } \\
\text { ) }\end{array}$ \\
\hline Nominal Mix & $\mathbf{2 . 2 7}$ & $\mathbf{2 . 5 7}$ \\
\hline $\begin{array}{l}\text { River sand (60\%) + } \\
\text { Quarry Dust (40\%) }\end{array}$ & $\mathbf{1 . 9 4}$ & $\mathbf{2 . 1 2}$ \\
\hline $\begin{array}{l}\text { C.A (60\%) +DCW } \\
\text { (40\%) }\end{array}$ & $\mathbf{2 . 6 3}$ & $\mathbf{2 . 8 9}$ \\
\hline $\begin{array}{l}\text { River sand (60\%) + } \\
\text { Quarry dust (40\%) \& } \\
\text { C.A (60\%) + DCW } \\
\text { (40\%) }\end{array}$ & $\mathbf{2 . 4 0}$ & $\mathbf{2 . 6 5}$ \\
\hline
\end{tabular}

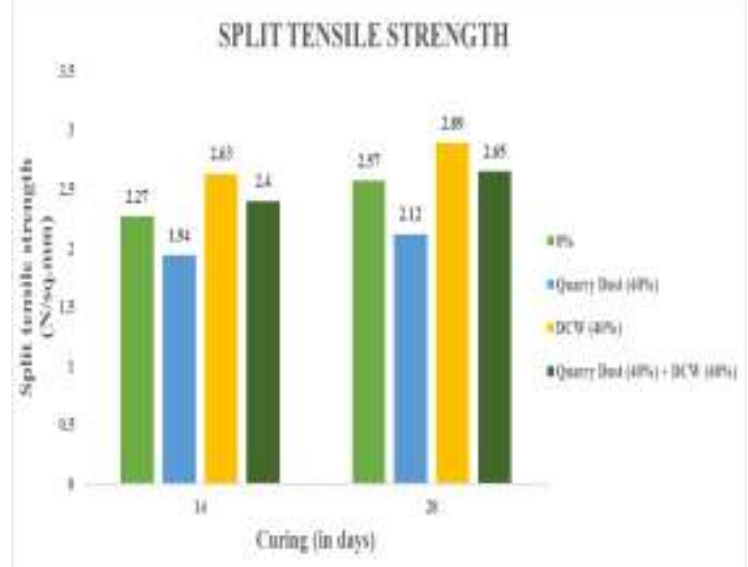

Figure 6.4 split tensile strength for various proportions of SF and RHA

\subsection{FLEXURAL STRENGTH}

"Flexural strength is one measure of the tensile strength of concrete. It is a measure of an unreinforced concrete beam or slab to resist failure in bending. It is measured by loading $100 \mathrm{~mm} \times 100 \mathrm{~mm}$ x $500 \mathrm{~mm}$ concrete beam".

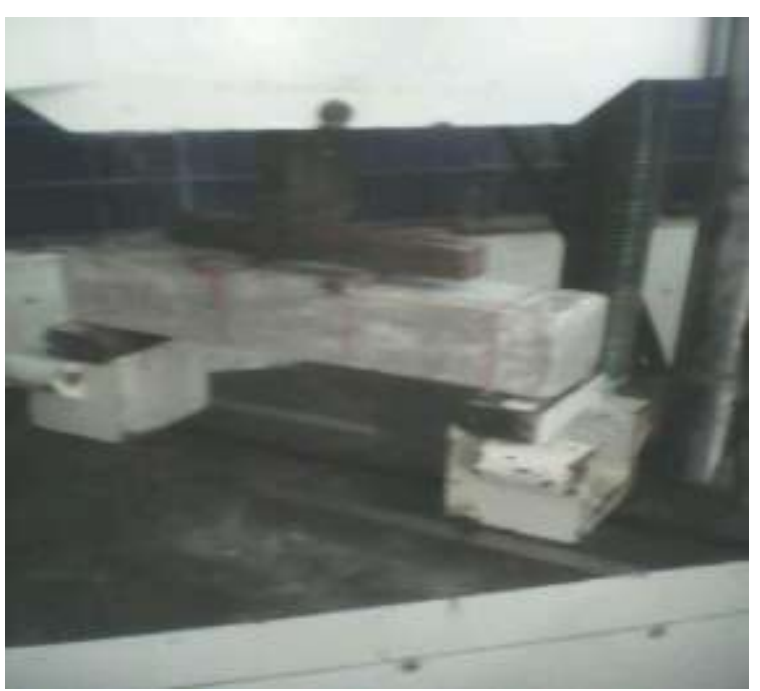

Figure 6.4 flexural testing machine

TABLE 6.3 TEST RESULTS FOR FLEXURAL STRENGTH

\begin{tabular}{|l|l|l|}
\hline Replacement Details & $\begin{array}{l}\text { 14 days } \\
\left(\mathbf{N} / \mathbf{m m}^{2}\right. \\
)\end{array}$ & $\begin{array}{l}\mathbf{2 8} \text { days } \\
\left(\mathbf{N} / \mathbf{m m}^{2}\right)\end{array}$ \\
\hline Nominal Mix & $\mathbf{3 . 5 8}$ & $\mathbf{4 . 1 1}$ \\
\hline $\begin{array}{l}\text { River sand (60\%) + } \\
\text { Quarry Dust (40\%) }\end{array}$ & $\mathbf{3 . 4 3}$ & $\mathbf{3 . 9 4}$ \\
\hline $\begin{array}{l}\text { C.A (60\%) +DCW } \\
\text { (40\%) }\end{array}$ & $\mathbf{3 . 7 6}$ & $\mathbf{4 . 3 0}$ \\
\hline $\begin{array}{l}\text { River sand (60\%) + } \\
\text { Quarry Dust (40\%) \& } \\
\text { C.A (60\%) + DCW } \\
(40 \%)\end{array}$ & $\mathbf{3 . 5 9}$ & $\mathbf{4 . 1 7}$ \\
\hline
\end{tabular}

Figure 6.4 flexural strength for various proportions

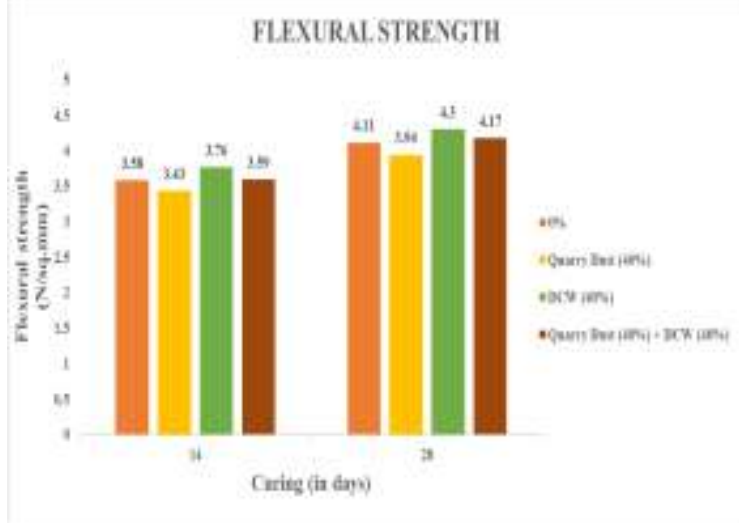

VII. CONCLUSIONS

\section{COMPRESSIVE STRENGTH}

- For River sand (60\%) + Quarry dust (40\%), the compressive strength has decreased to about 
$23.6 \mathrm{~N} / \mathrm{mm}^{2}$ from $25.1 \mathrm{~N} / \mathrm{mm}^{2}$ when compared to conventional concrete.

- For C.A $(60 \%)+$ Demolished concrete waste (40\%), the compressive strength has increased to about $27.5 \mathrm{~N} / \mathrm{mm}^{2}$ from $25.1 \mathrm{~N} / \mathrm{mm}^{2}$ when compared to conventional concrete.

- For River sand $(60 \%)+$ Quarry dust $(40 \%)$ \& C.A $(60 \%)+$ Demolished concrete waste $(40 \%)$, the compressive strength has increased to about $25.4 \mathrm{~N} / \mathrm{mm}^{2}$ from $25.1 \mathrm{~N} / \mathrm{mm}^{2}$ when compared to conventional concrete.

\section{SPLIT TENSILE STRENGTH}

- For River sand (60\%) + Quarry dust (40\%), the split tensile strength has decreased to about 2.12 $\mathrm{N} / \mathrm{mm}^{2}$ from $2.57 \mathrm{~N} / \mathrm{mm}^{2}$ when compared to conventional concrete.

- For C.A (60\%) +Demolished concrete waste $(40 \%)$, the split tensile strength has increased to about $2.89 \mathrm{~N} / \mathrm{mm}^{2}$ from $2.57 \mathrm{~N} / \mathrm{mm}^{2}$ when compared to conventional concrete.

- For River sand (60\%) + Quarry dust (40\%) \& C.A $(60 \%)+$ Demolished waste $(40 \%)$, the split tensile strength has increased to about 2.65 $\mathrm{N} / \mathrm{mm}^{2}$ from $2.57 \mathrm{~N} / \mathrm{mm}^{2}$ when compared to conventional concrete.

\section{FLEXURAL STRENGTH}

- For River sand $(60 \%)+$ Quarry dust $(40 \%)$, the flexural strength has decreased to about 3.94 $\mathrm{N} / \mathrm{mm}^{2}$ from $4.11 \mathrm{~N} / \mathrm{mm}^{2}$ when compared to conventional concrete.

- For C.A (60\%) +Demolished concrete waste (40\%), the flexural strength has increased to about $4.30 \mathrm{~N} / \mathrm{mm}^{2}$ from $4.11 \mathrm{~N} / \mathrm{mm}^{2}$ when compared to conventional concrete.

- For River sand $(60 \%)+$ Quarry dust $(40 \%) \&$ C.A $(60 \%)+$ Demolished concrete waste $(40 \%)$, the flexural strength has increased to about 4.17 $\mathrm{N} / \mathrm{mm}^{2}$ from $4.11 \mathrm{~N} / \mathrm{mm}^{2}$ when compared to conventional concrete.

\section{REFERENCES}

[1] IS 10262: 2009, "Concrete Mix Proportioning - Guidelines".

[2] IS 456: 2000, "Plain and reinforced concrete - code of practice".

[3] IS 383: 1970, "Specification for coarse and fine aggregates from natural sources for concrete". Bureau of Indian Standards, New Delhi.

[4] Strength and durability properties of concrete containing quarry rock dust as fine aggregate, R.Ilangovana, N.Mahendrana and K.Nagamanib,ARPN Journal of Engineering and Applied Science, October 2008.
[5] Study of Properties of SCC using 'Quarry Dust' and 'Fly Ash', M.V. Rama Raju, K.V.Vivek, Dr.T.Siva Shankar Reddy and P. Srinivas Reddy, International Journal if Engineering Science Research, Vol 02, Issue 04, August-September 2011.

[6] "Partial replacement of Sand with Quarry Dust in Concrete" Chandana Sukesh, Katakam Bala Krishna, P.Sri Lakshmi Sai Teja, S.Kanakambara Rao.

[7] Characteristic studies on the mechanical properties of quarry dust addition in conventional concrete, A.Sivakumar and Prakash M, Journal of civil engineering and construction technology, October 2011.

[8] Use of Crushed Granite Fine as Replacement toRiver Sand in Concrete Production, Manasseh JOEL, Leonardo Electronics Journal of Practice and Technologies, July- December 2010.

[9] Hansen, T.C. (1992). "Recycling of demolished concrete and masonry". RIELM Report No.6, E. and F.N. Spon, UK.

[10] ASTM"C805/C805M-08 Standard Test Method for Rebound Number of Hardened Concrete." ASTM International, West Conshohocken, Pennsylvania.

[11] Chen H.J, Yen T, and Chen K.H. (2003). "Use of building rubbles as recycled aggregates."Cement and Concrete Research, 33(2003), 125-132.

[12] Elias-Ozkan, S. T. (2001). "Recycling rubble into aggregates: a model for local governments."Habitat International, 25(4), 493-502.

[13] Padmini A.K, Ramamurthy K, Mathews M.S. (2002). "Relative moisture movement through recycled aggregate concrete" Cement and Concrete research, 54(5), 377384.

[14] Collins, R.J. (1994). "The use of recycled aggregates in concrete". BRE report, Building Research Establishment, U.K. May. 
International Journal of Engineering Research and Applications (IJERA) is UGC approved Journal with S1. No. 4525, Journal no. 47088.

N. .Devendran. "Experimental Analysis of Concrete with Quarry Dust and Demolished Concrete Waste." International Journal of Engineering Research and Applications (IJERA) 7.7 (2017): 39-44. 